\title{
Yeni Toplumsal Hareketler: Bir Literatür Taraması
}

\author{
Elif TOPAL DEMİROĞLU*
}

\section{Özet}

1960’larla birlikte siyasal ve toplumsal alanda yaşanan dönüşüme koşut olarak geçmişte hâkim olan hiyerarşik ve merkezi örgütlenmeleri temel alan toplumsal hareketler yerlerini daha esnek, merkezi olmayan ve heterojen yapılara bırakmıştır. Geçmişle bağlarını tamamen koparmamış olsalar da katılımcılar, örgütlenme yapıları, amaçları, değerleri, duyguları, araçları ve kullandıkları yöntemlerde farklılıklar ortaya çıkmıştır. Bu dönüşüm ile birlikte toplumsal hareketler yaklaşımlarında yeni açıklamalar ortaya çıkmıştır. Bu çalışma yeni toplumsal hareketlerin açıklamalarının siyasal alan tanımı, hareketlerdeki aktörler ve hareketlerin örgütlenme yapıları çerçevesinde yeni toplumsal hareketlerin literatür taramasını yapmayı amaçlamaktadır.

Anahtar Kelimeler: Toplumsal hareketler, yeni toplumsal hareketler, literatür taraması

\section{New Social Movements: A Literature Review}

\section{Abstract}

From the 1960s onward hierarchical and centrally organized social movements of past have been replaced by more flexible, decentralized and heterogeneous structures with transformations occurred in political and social areas. Although they did not break with the past movements completely, these movements entail novel features with respect to their actors, organizational structures, objectives, values, strategies and methods. Alongside these transformations, new perspectives analyzing new social movements have emerged within the field of the social movements literature. This study aims to review the new social movements literature focusing on the analyses of some prominent thinkers of this approach.

Keywords: Social movements, new social movements, literature review

\footnotetext{
* Araştırma Görevlisi, Marmara Üniversitesi Siyasal Bilgiler Fakültesi Kamu Yönetimi Bölümü (Türkçe). E-mail: eliftopal@gmail.com
} 


\section{Giriş}

Dünyanın köklü değişimi ve dönüşümünün yaşandığı, ekonomik, politik ve sosyal yapıların hızla değiştiği bir döneme tanıklık ediyoruz. Özellikle 20. yüzyılın ortalarından itibaren hızlanan sanayileşme, kentleşme, modernleşme gibi süreçlere, küreselleşmenin de eklenmesiyle toplumlardaki değişimler hem ortaya çıktığı coğrafyada etkisini göstermekte hem de yaygın iletişim kanalları ile kıtalar ötesine etki edebilmektedir. Bütün bu değişim ve dönüşüm içerisinde toplumsal olanın ve toplumsal aktörlerin konumu ve rolü yeniden gündeme gelmekte ve tartışılmaktadır. 1960'lardan itibaren dünyada açıkça gözlenen derin ve hızlı dönüşüm ile birlikte sistem karşıtı hareketlerin de dönüşüm geçirdiği söylenebilir. 1960'ların öğrenci, yeni sol ve sivil haklar hareketleri; 1970 ve 1980’lerin LGBT, çevre, kadın, barış ve insan hakları hareketleri; 1990'ların ve 2000'lerin 'küresel adalet hareketi’ birbirinin ardı sıra ortaya çıkmış ve gittikçe genişlemiştir. Toplumsal düzlemde yaşanan bu değişimler toplumsal hareketlerin ortaya çıkış nedenlerini, katılımcılarının özelliklerini, hedeflerini ve hareket biçimlerini de değişikliğe uğratmıştır. Böylece, kimliğe dayalı yaklaşımların yoğunluk kazandığı, meselelerin çeşitlendiği ve ilk bakışta sınıf temelli olmadığı izlenimini yaratan toplumsal hareket türleri ortaya çıkmıştır. Yeni orta sınıfların belirgin olarak katılımının arttığı, iktidarı ele geçirerek dönüştürmeyi hedeflemeyen, özellikle kültürel alanın değişimini hedef olarak alan ve kimlik yöneliminin ağır bastığı bu 'yeni' toplumsal hareketlerle beraber, bu hareketleri inceleyen toplumsal hareketler teorilerinde de yenilikler meydana gelmiştir.

Yeni toplumsal hareketleri inceleyen teorilerin incelendiği bu çalışmada, bahsi geçen hareketler içinde bulundukları siyasi alanlar, hareketlerin taşıyıcısı olan toplumsal öznenin kim veya kimler olduğu ile hareketlerin geleceğe yönelik taleplerini somutlaştırabilecekleri kurumsal alan üzerinden değerlendirilecek ve bu bağlamda yeni toplumsal hareket kuramına getirilen eleştirilere yer verilecektir.

\section{Toplumsal Hareketlerde Yaşanan Dönüşüm}

Genel anlamiyla toplumsal hareketler, "[e]litlere, otoritelere, başka gruplara ya da kültürel kodlara karşı, elitler, diğer gruplar ve unsurlarla kalıcı bir etkileşim içinde, ortak hedeflere sahip ve dayanışma içinde olan bireyler tarafından geliştirilen kolektif eylemler” olarak tanımlanmaktadır (Tarrow, 2011:7). Tarihte farklı coğrafyalarda ortaya çıkan toplumsal çatışma ve talepler, ulusal devletlerin tam olarak şekillendiği ve güçlerini pekiştirdikleri 19. yüzyıldan itibaren yukarıda verilen tanıma uygun toplumsal hareketler olarak ifade edilmeye başlanmıştır. Bu bağlamda modern toplumsal hareketlerin gelişim sürecinde 19. yüzyılın ikinci yarısı başlangıç olarak kabul edilmektedir. Tilly’e (2008) göre 19. yüzyılda çok önemli bir değişim meydana gelmiş ve geleneksel olarak cemaat grupları tarafından gerçekleştirilen savunmacı eylemlerden organize, öz bilincine sahip, daha kalıcı hareketlere ve yeni haklar ile fırsat arayışlarında olan eylemlere doğru bir dönüşüm yaşanmıştır.

1960'ların sonlarında ise dünyada açıkça gözlenebilen derin ve dramatik bir dönüşüm söz konusu olmuştur. 1960’ların sonu ve 1970’lerin başındaki sivil haklar, ifade özgürlügü ve 
öğrenci; 1970’lerdeki kadın, barış ve çevre/ekoloji hareketleri; ve 1980'lerle yaygınlaşan nükleer silahsızlanma hareketlerinin niteliğindeki farklılıklar köklü dönüşümün göstergeleri olarak değerlendirilmektedir. Yayılan ve derinleşen modernitenin farklı unsurlarının neden olduğu sorun ve bunalımlar karşısında çeşitli amaç ve aktörlerle ortaya çıkan bu toplumsal hareketler, "yeni toplumsal hareketler” olarak kavramsallaştırılmıştır.

1960'lardan itibaren ortaya çıkan toplumsal hareketleri kavramsallaştıran iki temel yaklaşım söz konusudur: Amerika merkezli Kaynak Mobilizasyonu Teorisi (Resource Mobilization Theory) ve Avrupa merkezli Yeni Toplumsal Hareketler Teorileri (New Social Movements Theories).

Kaynak Mobilizasyonu Teorisi çerçevesindeki analizler, toplumsal hareket örgütlerini merkeze alırken; hareketlerin içki kaynaklarına, kaynak yönetimi kararlarına, örgütsel dinamiklerine ve -Kaynak Mobilizasyonu Teorisi'nin alt kolu olan Siyasi Fırsat Yapıları (Political Opportunity Structures) yaklaşımında olduğu gibi- hareketlerin içinde bulundukları siyasal bağlam ve değişikliklere odaklanır. Buna bağlı olarak; bir toplumsal hareketi oluşturan meseleler ve aktörler verili olarak ele alınırken ve aktörlerin kendi çıkarlarını takip etmek için stratejilerini nasıl geliştirdiklerine ve çevre ile nasıl etkileşim kurduklarına üzerinde durulur. Bu nedenle, Kaynak Mobilizasyonu Teorisi toplumsal hareketleri açıklarken amaçsal bir model kullanır ve hareketlerin stratejik-araçsal yönüne referans verir (Tilly, 1985: 740-41; della Porta ve Diani, 1999; Tarrow, 2011). Buna bağlı olarak, Kaynak Mobilizasyonu teorisyenleri 1960'larla beraber ortaya çıkan hareketleri, daha önceki dönemlerde meydana gelen hareketlerden bir kopuş olarak nitelemek yerine, aradaki benzerliklere ve devamlılıklara işaret ederler.

$\mathrm{Bu}$ yazının ana konusu olan Yeni Toplumsal Hareketler (YTH) Teorisi'nin köklerini kıta Avrupa'sı merkezli sosyal teorisi ve siyaset felsefesi geleneğinde bulmak mümkündür. Kuram çerçevesinde, 'yeni' olarak değerlendirilen 1960 sonrası hareketlerin, ekonomik ve kurumsal siyaset kaynaklı sorunlar yerine eşitlik, farklılık katılım ve kimlik inşasına ilişkin meselelere odaklandığını savunur. KlasikMarksizm’in kolektif davranışa iliş̧in indirgemeci yapısal yorumuna ve Kaynak Mobilizasyonu teorilerinin toplumsal hareket örgütü ve strateji odaklı analizlerine cevaben YTH teorisyenleri, hareketlerin farklı dinamiklerinden yola çıkarak, yeni toplumsal hareketlerin nasıl birer kolektif davranış olarak ortaya çıktığının kuramsal çerçevesini çizerler. Buechler'in (1995) belirttiği gibi içerdikleri farklılıklara rağmen hemen tüm YTH kuramcıları, klasik liberalizmin yapısal özelliklerinin işçi eylemlerinin dinamiklerini şekillendirdiğine benzer şekilde post- endüstriyel veya gelişmiş kapitalist toplum olarak adlandırılan toplumsal formasyon döneminin de mevcut kolektif davranış türlerini şekillendirdiği konusunda hem fikirdirler. YTH teorileri, 1960'larla birlikte dönüşmeye başlayan Batı'daki yeni toplumsal yapı içerisinde meydana gelen yeni toplumsal hareketleri makro düzeyde dönüşen ekonomik yapı ile ilişkilendirirken, mikro düzeyde kimlik oluşum süreçlerinin ve kişisel davranışın toplumsal hareketler üzerindeki etkisine bakar (Pichardo, 1997: 411).

\section{Yeni Toplumsal Hareketlerinin Toplumsal ve Siyasal Alanı}

Yeni toplumsal hareketler olarak adlandırılan ve 1968 sonrası siyaset sahnesinde yükselen hareketlerin ortak yönlerinden en önemlisi mücadeleyi geçmişteki deneyimden faklı bir biçimde 
ve bağlamda sürdürmeleridir. Burada bahse konu olan farklılık tam da hareketin yeniliği ve kendini nasıl bir toplumsal bağlam içerisinde tanımladığı ile ilgilidir. Yeni toplumsal hareketler, modernliğin ilk dönemlerinde daha çok işçi sınıfı üzerinden ekonomik çıkar eksenli ve siyasal gücü ele geçirmek/etkilemek üzere ortaya çıkan toplumsal hareketler olarak tanımlanan "eski" hareketlerin dinamiklerini içermekle birlikte, eskiden farklı olarak esnek, merkezsiz olması ve yerelde oluşan tepkilerin kolektif hâle gelmesinden oluşmaktadır. ${ }^{1}$ Touraine'e (1999) göre, yeni toplumsal hareketler 1970'lerin endüstriyel toplumsal yapısına karşı çıarak endüstri sonrası (post- endüstriyel) bir toplum yapısına dayanmaktadır. Yeni dönem çatışmalarının ve çelişkilerinin belirlendiği bir alanda var olan yeni toplumsal hareketler önceki dönemlerle karşılaştırmalı olarak kavramsallaştırılmakta ve daha heterojen bir yapı sergilemektedir. Karşılaştırmalı bir tanımlamaya duyulan ihtiyaç yeni toplumsal hareketlerin yeni bir egemenlik ilişkisi ve çatışmacı kültürel alan içerisinde ortaya çıktığını ve hareketlerin analizinde bu "yeni" alanın tanımlanması zorunluluğudur. Laclau ve Mouffe (1985) yeni egemenlik ilişkilerini tanımlarken İkinci Dünya Savaşı̇ndan sonra gelişen "yeni hegemonik formasyona" karşı şekillenen yeni toplumsal hareketlerin gelişim süreci üç aşamada değerlendirmektedir: Birincisi, ekonomik düzeyde yaygın birikim rejiminden yoğun birikim rejimine geçiş ile birlikte ortaya çıkan toplumsal ilişkilerin metalaşması; ikincisi, refah devletinin müdahaleci karakteri ve toplumsal ilişkilerin metalaşmasının bir sonucu olarak devletin daha geniş alanlara müdahale etmesiyle birlikte yeni çatışma biçimleri ortaya çıkması ve sonuncusu kitle iletişim araçlarının gelişmesi ile ortaya çıan tektipleştirici bir kitle kültürünün yeni egemenlik ilişkileri ve dolayısıyla çatışma biçimlerini ortaya çıkarmasıdır.

$\mathrm{Bu}$ çatışma ve çelişkiler Touraine’e (1999) göre temel sosyal sınıflar olan tüketici/müşteri ile yöneticiler ve teknokratlar arasındaki kültür çatışmasıdır. Burada kültür, yaşamsal olanın kurulduğu alan olarak tanımlanırken, kültürün temel çatışma alanı olması ise taleplerin materyal ve ekonomik olandan post-materyal değerlere doğru yön değiştirmesi ile ilgilidir. Böylelikle, yeni toplumsal hareketlerin üzerinde yükseldiği yeni bir toplumsal bağlam ve siyasal ortaya çımıştır. Inglehart’nn (1977) vurguladığı gibi değerler değişime uğramakta ve yeni hareketler de materyal değerlerden ziyade ahlak, bireysel gelişim ve yaşam kalitesini geliştirmek ve özgürlük gibi postmateryal değerlerin savunucusu olmaya soyunmaktadır. Yeni toplumsal hareketlerin postmateryal değerlerin savunucusu olduğu tezinin bir başka boyutu da bu hareketlerin daha fazla konuyu siyasetin alanına dâhil etme çabasıdır. Bu bağlamda yeni toplumsal hareketlerin en önemli özelliklerinden biri, siyasetin konusu haline getirdiği konuları kamuoyu önünde tartışmaları ve resmi kurumları bu konuları gündemlerine almaya zorlamalarıdır. Böylece, devletin kamusal müdahale yoluyla toplumsal grupları oluşturma ve yeniden üretme kapasitesi, çok sayıda parçalı

\footnotetext{
1 "Eski” ve "yeni” toplumsal hareketler ayrımı, 'eski' ve 'yeni' siyasetin temel değer ve temaları üzerinden yapılmaktadır. Bu kavramsallaştırılmaya göre, 'eski' siyasette materyal değerler önceliklidir; temsili demokrasi siyasetin ana mekanizması olarak görülür; ekonomik, sosyal ve güvenlik konuları ekseninde mobilizasyon sağlanır ve örgütlenme siyasi partiler ve merkezi işçi sınıfı hareketleri etrafında gerçekleşir. 1960'larla beraber ortaya çıkan 'yeni' siyaset ise, özgürlük ve kimlik değerleri post-materyal değerleri, katılımcı demokrasi hedefini, çevre, ifade özgürlüğü, gay/lezbiyen hakları, barış, feminizm gibi konulara yönelimi ve hareketlerin taşıyıcıları olarak da kurumsal siyasetin dışında örgütlenen yeni orta sınıfı, gençleri ve eğitimlileri kapsar. Eski ve yeni siyaset kavramları hakkında daha detaylı bilgi için bkz. Offe, 1985.
} 
ve aracılık etmesi zor taleplerin kamuoyu önünde dile getirilmesiyle aşınmıştır. Hareketin içinde yer alan aktörlerin tanınma ve söz sahibi olma istekleri ile birlikte toplumdaki vatandaşlık algısının yeniden ele almasinı zorunlu hale getirir (della Porta ve Diani, 1999: 197-198).

Touraine'in (1999) analizi üzerinden, yeni toplumsal hareketlerin çizgisel bir gelişim ve düzenli bir ilerleme göstermekten ziyade çatışmalı, çelişkili, inişli çıkışlı ve yoğun iletişime dayalı yatay bir süreci ifade ettiğini söylemek mümkündür. Touraine'in (1988: 41) toplumsal hareket anlayışında tarihsellik (historicity) merkezi bir yer tutar. Tarihsellik, toplumsal uygulama ve pratiklerin üzerine oturduğu kültürel modellerin belirlenmesine tekabül eder. Toplumda, tarihselliği ele geçirmek için yöneten gruplarla diğerleri arasında anlaşmazlık yükselir. Toplumdaki yönetici grupla geri kalan nüfus arasındaki anlaşmazlık, toplumun merkezi anlaşmazlığıdır. Daha açık bir ifadeyle, tarihsellik kavramı çerçevesinde toplumdaki merkezi anlaşmazlık yaygın kültürel modelleri üzerine meydana gelirken; "kendilerini bu modellerin aktörleri ve sahipleri olarak görenler" ile "onları ancak bağımlı bir konumda anmakla yetinen ve bu kültürel modelleri yöneten toplumsal güçten ayırmayı amaçlayanlar" arasında gerçekleşir. Yeni toplumsal hareketlerin yalnızca bir iktidar eleştirisi perspektifi değil; aynı zamanda yerleşik siyaset ve toplumsal düzen eleştirisini de içerdiği söylenebilir. Düzen eleştirisi özellikle gündelik yaşam ile ilişkilidir ve gündelik olanın siyaset alanına dâhil edilmesi çabasını da beraberinde getirir. Sosyal ihtiyaçların piyasaya bağlanması ile toplumsal yaşam metalaştırılmaktadır ve devletin tüm toplumsal yeniden üretimin süreçlerine girmesinin sonucu olarak toplumsal yaşamın bürokratikleşmektedir. Kolektif kimlikleri şekillendiren ya da onları yok eden kitle medyasının etkisiyle de, toplumsal yaşamın kültürel yığınlar haline getirilme biçimleri, bunlara karşı koyan direncin yeni biçimleriyle ifade edildiği yeni toplumsal hareketlerin yükselişine neden olmaktadır (Mouffe, 1984).

Yeni toplumsal hareketlerin yaşam alanı ile ilgili taleplerin taşıyıcısı olduğu tezi Habermas tarafından 'yaşam alanlarının kolonileşmesi' ve yeni toplumsal hareketlerin yükselişi arasında bağ kurularak açıklanmıştır. Habermas, anlamın ve özgürlüğün kaybolması, daha önceki geleneğin sorgulamadığı konuların geri dönülemez bir şekilde sorgulanır hale gelmesi ve yönetim yapısının da bu sorunlar karşısında yetersiz kalması sonucunda yeni toplumsal hareketlerin yükseldiğini ifade etmektedir (Crossley, 2002: 162). Kültürel yeniden üretim, sosyal entegrasyon ve sosyalizasyon gibi alanlarda doğan yeni çatışmalar, ekonomik dağılım problemlerinden değil, yaşam biçiminin düzenlenmesine bağlı sorular tarafından tetiklenir (Habermas, 1981). Yeni toplumsal hareketlerin refah ve ekonomik yeniden dağitım sorunlarından çok, kültürel yeniden üretim, toplumsal bütünleşme ve sosyalizasyon üzerine odaklanmış olması Habermasinn teorisi açısından önem taşır. Zira bu hareketler devlet ve ekonominin baskıcı yapısının ve yaşam alanlarının kolonileştirilmesine karşı yaşam alanlarının özgürleşmesine yönelik taleplerde bulunurlar ancak yalnızca ekonomik çıkara yönelik talepleri yoktur.

Yeni toplumsal hareketlerin ortaya çıkışını kapitalist dinamiklerin kentsel mekânın dönüşümüne etkisine ve bu süreçte meydana gelen eylemlere odaklanarak analiz eden Castells (2008), hem sinıfa bağlı hem de sinıf temelli olmayan aktörlerin/taleplerin kentsel toplumsal hareketlerdeki rolünü kabul eder. Castells, kenti bir sosyal meta olarak ele alırken bu metanın çatışan toplumsal çıkar ve değerlerin bir sonucu olduğunu belirtir. Castells (2008: 100), 
toplumsal hareketlerin üç tanımlayıcı ilkesi bulunduğunu ve bu ilkeler olmadan herhangi bir toplumsal hareketin açıklanmasının mümkün olmadığını savunur. Buna göre, hareketin ortak kimliği, hareketin karşıtı ve toplumsal hedef olmak üzere belirlenen üç temel kriteri göz önünde bulundurmak gerekmektedir. Castells, kenti toplumsal çelişkilerin ürettiği mekan olarak tanımlarken aynı zamanda bu toplumsal çelişkilerin hem sınıf çıkarları hem cinsiyet, kimlik, milliyet ve vatandaşlık gibi kimliklere bağlı talep ve çıkarları içerdiğini kabul etmektedir (Buechler, 1995: 443).

Yeni toplumsal hareketlerin eskiden tamamen bir kopuş olarak nitelendirmeden, süreklilik bağlamında ele alan Eder (1985) ise, yeni toplumsal hareketlerin eski ile benzeşen unsurları barındırdığını ve iki tür fenomeni ele aldığını belirtir: mevcut sosyal yaşam biçimine karşı çıan kültürel hareketler ve modern devlet egemenliğine karşı çıkan siyasi hareketler. Yaşam alanı ile ilgili yükselen taleplerin siyaset alanında yer bulması amacını taşıyan yeni toplumsal hareketler, gündelik hayatın da siyasallaştırılması vurgusunu yapmaktadır. Bu husus ile ilgili kavramsallaştırma Offe tarafından yapılmaktadır. Offe (1985), yeni hareketlerin batıda refah toplumunun karşı karşıya kaldığı tehditler neticesinde ortaya çıktığını belirtmektedir. Liberal refah devletinin düzenlemeleri altında, insanların çoğunun enerjisini aile, iş, tüketim merkezli hayat kalıplarına yönelteceğini; bu sebeple kamu politikalarına katılım ve bu politikalar üzerindeki çatışmanın toplumun genelinde önemli bir yer tutmayacağı varsayımının artık geçerli olmadığını söylemektedir. Dolayısıyla gündemi meşgul eden konular gelir dağılımı, ekonomik büyüme ve toplumsal statülerin hukuksal açıdan korunması gibi hususlar olmuştur. Bütün bu önemli hususlar liberal demokrasi ve refah devlerinin hareket alanında sınırlı kalmıştır. Ancak yeni toplumsal hareketlerin hareket alanı "kurumsal olmayan" siyaset alanıdır (Offe, 1985).

$\mathrm{Bu}$ kimlikleri sahiplenen ve toplumsal olarak görünür hale gelmiş olanın siyasal alana da yerleşmesini sağlamaya çalışan toplumsal öznenin kimler olduğu ise yeni toplumsal hareketlere katılan aktörlerin kimlik ve tutumların anlaşılması ile mümkündür.

\section{Yeni Toplumsal Hareketlerin Toplumsal ve Siyasi Öznesi}

Yeni toplumsal hareket kuramcıları, kolektif kimlikleri/tutumları ve sosyal çatışmaları, toplumsal hareketliliği oluşturan aktörler olarak görmekte ve hareketleri incelerken aktörlerin oluşum süreçlerine odaklanmaktadırlar.

Yeni toplumsal hareketlerin analizinde toplumsal ilişkilerin yalnızca materyal değerler etrafında şekillenmediği; hak talebinde bulunan toplumsal öznenin de yalnızca sınıfsal aidiyetlerle sınırlı kalmadığı görülmektedir. Başka bir ifadeyle, eski toplumsal hareketler yalnızca işçi sınıfı tabanlı iken yeni toplumsal hareketlerin farklı bir toplumsal sınıf tabanlı olduğu kabul edilmektedir (Buechler, 1995: 453). Sosyal ve siyasal alanda daha fazla söz sahibi olmak isteyen toplumun üyelerinin, yerleşik düzenin işleyişi ve uygulamalarından memnun olmayan ve mevcut düzenin değişimi için mücadele eden kesimlerin yeni toplumsal hareketlerin taleplerinin taşıyıcıları olduğu gözlemlenmektedir. 
Yeni toplumsal hareketlerin aktörleri homojen bir görünüm sergilemeyen, farklı toplumsal, ekonomik ve kültürel geçmişten gelen özneler olarak değerlendirilmektedirler. Hareketlere katılanların kimler olduğu yönündeki en bilinen açıklama hizmet sektöründe çalışan ve yeni oluşmuş yeni orta sınıfların olduğudur. Offẻnin (1999: 65-66) belirttiği gibi yeni toplumsal hareketlerin tabanıyeni orta sınıfa dayanmaktadır. Eski tip toplumsal hareketlerin grup dinamiğiyle hareket ettiğini ve çatışmalara doğrudan taraf olarak dâhil olduğunu ancak yeni toplumsal hareketlerin grup davranışı sergilemekten uzak topluluklar aracıllğıyla gerçekleştirildiğini belirtir. Offe (1999: 68), yeni toplumsal hareketlerin toplumsal tabanının üç öğeden oluştuğunu söylemektedir: Yeni orta sınıf -özellikle hizmet ve/veya kamu sektörü çalışanları-; eski orta sınıfın unsurları ve son olarak iş piyasasının dışında kalan insanlar. Bu aktörler, yönlendirme mekanizmaları (steering mechanisms) olarak devlet ve piyasanın gelişme/büyüme rasyonalitesi ile özel yaşam alanını şekillendirme girişim ve müdahalesine -diğer bir deyişle yaşam alanlarının kolonileşmesine- direnen aktörlerdir (Habermas, 1981; Offe, 1985). Touraine (1999: 47) ise, yeni toplumsal hareketlerin aktörlerinin tarihin içine yerleşmekten çok, tarihsel durumların aktörler tarafından üretildiği üzerinde durur. Aktörler kendi yaratıcılıkları üzerine düşünebilmektedir ve yeni toplumsal hareketler de aktör/öznelerin keskin bilinci ile gerçekleşmektedir. Yeni orta sınıf tabanı üzerinden şekillenen sınıf tanımlamasında aktörler, kendi çalışma özerkliklerine el uzatılan ve iş üzerindeki kontrolleri uzmanlık ve becerileri olan profesyonellerdir (Pichardo, 1997: 417). Bu tanımlama kendi çalışma ilişkilerinde herhangi bir kontrolü bulunmayan ve emek gücü ile üretim ilişkilerinin içerisinde var olan iş̧̧i sınıfının yerine uzmanlık ve profesyonelliği ile çalışma sürecini kontrol edebilen yeni orta sınıf tabanını koymaktadır. Yeni toplumsal hareketlerde yer alan aktörler, yüksek düzeyde kültürel farkındalığa sahip olan özneler olarak nitelendirilmektedir. Siyasal aktörü tanımlayan kriterlerin değişmesi, kolektif aidiyetlerin ve harekete geçen çıkarların çoğullaşmasına ve bu nedenle gittikçe bölünmesine neden olmaktadır (della Porta ve Diani, 1999). Yeni toplumsal hareketler, tanımladığı yeni siyaset alanının kültürel içeriği ile belirli kesimlerin taleplerine odaklanmakta ve hareketlerin bir bütün olmaktan ziyade parçalı bir şekilde ilerlemesine neden olmaktadır. Bu nedenle hareketler kültürel hareket, sınıfa karşı kimlik hareketleri gibi ayrımları doğurmuştur (Yıldırım, 2012: 75).

Yeni toplumsal hareketlerin geleneksel anlamda bir sınıf hareketi olmadığını ancak yeni bir tür sınıf ilişkisi ortaya çıktığını, gelişmiş kapitalist toplumlarda sınıf ve kolektif davranışın birbirinden ayrışmış durumda olduğunu ve kültürün müdahaleci rol oynadı söylenebilir (Eder, 1985). Bütün kolektif aktörler yapısal olarak belirlenmekten ziyade toplumsal olarak oluşturulmakta ve bu oluşum süreci dönüştürücü ve kolektif içeriği ön plana çıkmaktadır. $\mathrm{Bu}$ bağlamda yeni toplumsal hareketler toplumsal özneyi, sadece bir seçmen olarak görmek yerine karar alma sürecinin hemen her aşamasında rol oynayan, iletişim kanallarını yoğun olarak kullanarak kamuoyu yaratma amacıyla ve diğer siyasi aktörler ile birlikte hareket eden aktif bir dönüştürücü haline getirmektedir.

Yeni toplumsal hareketlerin dönüştürücü içeriği Melucci’ye göre kültürel bir yapı içerisinde gerçekleşmektedir. Melucci (1985), hareketlere katılan aktörlerin yalnızca maddi bir kazanım peşinde olmadıklarını, sembolik ve kültürel menfaatleri için savaştıklarını belirtmektedir Bugünün toplumsal hareketleri, hem dış dünyamızın hem de doğamızın radikal dönüşümler 
geçirdiğini gösteren işaretlerdir. İçinde yaşadığımız gerçekliğin tamamıyla kültürel bir yapı haline geldiği ve bu gerçekliğe dair sahip olduğumuz temsillerin dünya ile kurduğumuz ilişkide süzgeçler gibi işlediği bir dönemde, sorunlar ve toplumsal aktörlerden söz ederken kullandığımız uluslar ötesi boyut, her şeyden önce insan eyleminin kültürel olarak kendi uzamını yaratabileceğinin göstergesidir. Dünyanın kültürel ve simgesel olarak algılandığı bu dönem, aynı zamanda insan eyleminin kültürel boyutunun üretim ve tüketim süreçlerinin temel hedefi haline gelişinin de zirve noktasıdır (Melucci, 1985: 10). Hareketin sahip olduğu bu grup çeşitliliği, sadece eylemlerde değil amaçlarda ve temel strateji konusundaki yaklaşımda da farklılığa yol açmaktadır (Tarrow, 2011). Hareketlerin siyaset alanına dâhil olma amaçları bağlamında ve toplumsal öznenin kimlerden oluştuğunu ele aldıktan sonra hareketlerin temel stratejileri kendilerini tanımladıkları kurumsal alan çerçevesinde değerlendirilecektir.

\section{Yeni Toplumsal Hareketlerin Kurumsal Alanı}

Önceki başlıklar altında belirtildiği üzere yeni toplumsal hareketler kültürel alana ve yaşamsal pratiklere odaklanmakta ve taleplerini bu çerçevede siyasallaştırmaktadırlar. Hareketlerin hangi talepleri dile getirdikleri ile birlikte bu taleplerin ne derece siyaset alanına eklemlenebildiği örgütlenme ve kurumsallaşma dinamiği açısından ele alınmalıdır. Toplumsal hareketlerin taleplerinin çeşitlenmesi ile birlikte örgütlenme biçimleri, siyasetin yalnızca bir iktidar mücadelesi olarak değerlendirilmesine karşı çıkış olarak ele alınmakta ve siyaset alanında var olma amacı ile paralellik seyretmektedir. Kurumsal alan olarak tarif edilmeye çalışılan aslında hareketlerin başarı kazanabilmesi ve tekil taleplerin bir araya gelerek kolektif bir talep haline dönüştürülmesinde rol oynayan araçsal yapıdır. Her ne kadar yeni toplumsal hareketler, ağlar, sosyal medya, forumlar, platformlar gibi zayıf bağlarla birbirine bağlanan bireylerin eylemi olarak ele alınsa da hareketin başarısını analiz etmede önemli bir nokta hareketin kendini tanımladığı kurumsal alandır.

Yeni toplumsal hareketlerin örgütlenme ve kurumsal yapılara bağlanma amacında olmadığınıve hareketlerin bir eylem süreci olarak nitelenebileceğini vurgulayan Bebbington (2007), hareketlerin dağınık, ama zaman ve uzam içinde sürekli, farklı yerleşmelerden aktörleri kapsayan ve sıklıkla farklı ölçeklerde gerçekleşen toplu eylem süreçleri olarak değerlendirmektedir. Hareket tipine göre önemli farklılıklar içerse de yerel birimlerin ve ağların önemli olduğu ve eski hareketlerin merkezi ve hiyerarşik örgütlenmesi ve parti örgütlenmelerinden özerk olarak pozisyon alma özellikleri ile eski tip toplumsal hareketlerden önemli bir farklılık teşkil etmektedir. Offe (1985), yeni toplumsal hareketlerin bir unsuru olarak ele aldığı hareket biçimlerini tanımlarken, yerleşiklik kazanmamış üyelik rolleri, programlar, platformlar, temsilciler ve üyelik aidatları temelinde yeni toplumsal hareketlerin katılımcılar, kapmayalar, sözcüler, ağlar ve gönüllü yardımlar ve katılımları içerdiğini belirtmektedir. Böylece bir siyasal örgütlenme olmaktan çok, bir süreç olarak nitelenen yeni toplumsal hareketler çatısı altında farklı geleneklerden gelen ve farklı dünya görüşlerine sahip olan bireyler belli ve özgül bir konuda birleşebilmektedirler (Çetinkaya, 2008: 36).

Offe (1985), Yeni toplumsal hareketlerin hareket alanının "kurumsal olmayan" siyaset alanı olduğunu belirtirken; hareketlerin genellikle normal siyasi kanalların ve katılım mekanizmalarının 
dışında kalmayı tercih ettiğini vurgulamaktadır. Bu noktada hareketlerin eylemlilikleri ve tasavvur ettikleri gelecek inşası kurumsal politikanın dışında bir kanal yoluyla mümkündür. Hareketin başarısının kendi doğasından getirdiği bu "bağlanmama" özelliğiyle birlikte değerlendirilmesi gerekmektedir. Ancak, Touraine ve onun kuramsal izleğini takip eden düşünürler, hareketlerin yalnızca talepleri ifade edici boyutta kalmayacağını, kurumsal bir boyuta geçerek yerleşik bir güç olacağını ve bu gücün de sivil toplumun içinden bir değiş̧imin göstergesi olacağı yorumunu yapmaktadır (Cohen, 1985). Bu nedenle, yeni toplumsal hareketlerin önemi de yaşanan dönüşümün taşıyıcı olmaları açısından sivil toplumun değiştirilip dönüştürülmesi ile ilgilidir (Touraine, 1999).

Yeni toplumsal hareketlerin örgütlenmelerinde ve kurdukları geçici siyasal ittifaklarda gözlenen esnekliğin, hareketlerin zamanın siyasal ve toplumsal gereklerine uygun düşmesini sağladığı; bu esnekliğin onlara, aynı derecede önemli olan farklı bileşenleri temsil eden farklı hareketlerin arasında gevşek ittifak kurma becerisi kazandırdığı da vurgulanmaktadır (Dirlik, 2008: 69). Melucci (1985) ise yeni toplumsal hareketlere dâhil olan grupların nükleer politikalara karşıtlık, barış, kürtaj gibi belirli konular temelinde ortaya çıktığını ve küçük gruplar hâlinde olsalar da oluşturdukları hareket ağının dinamik ve bir değiş-tokuş sistemi olduğundan bahsetmektedir. Yeni toplumsal hareketlerin genel örgütlenme biçimleri, yerel bir tabana ya da küçük gruplara dayalı olarak, özel ya da yerel sorunlar etrafında, toplumsal nitelikteki bir hareket çemberiyle ve akıcı hiyerarşiler ve serbest otorite dizgelerle, hareketli ve değişken üyelerden oluşan toplumsal ağlarıdır (Scott 1990: 19).

Yeni olanın farklı ve alternatif katılım ve karar alma yöntem ve kanalları aramasıdır. Nasıl ki hareketler yaşamın her alanına yayılan ve bu alanları etkileyen bir siyaset algısı üzerinden şekilleniyorsa, hareketlerin taşıyıcısı olan aktörlerin bir araya gelme şekilleri de gündelik hayatın dinamikleri gibi farklı ve dağınık olabilmektedir. Bu nedenle hareketlerin kullandığı taktikler, eylem biçimleri ve stratejiler de gündelik hayatla iç içe geçmiş çeşitli içeriklere sahiptir. Dolayısıyla, yeni toplumsal hareketlerin kulland ı̆̆ taktikler, temel amaç olarak belirledikleri "kimlik" talebinin bir yansıması olarak karşımıza çıkmaktadır. Kamuoyunu harekete geçirebilmek için kostüm ve sembolik gösterimlerle dolu son derece dramatik ve önceden planlanmış formları kullanma eğilimindedir (Tarrow, 1994). Toplumsal hareketleri gerçekleştiren gruplar, çeşitli talepleri dile getirebilmek, bunları iktidarın gündemine sokabilmek ve daha fazla insanı kendi hareketlerine çekebilmek için kullandıkları araçlar eylem repertuarlarıdır. Gruplar amaç ve stratejilerine uygun taktikleri ve eylem biçimlerini seçer ve bunlara yenilerini ekler. Çeşitli siyasal eylem türlerinin gerçekleştirilmesi özel amaçlı dernekler, birlikler kurmak, mitingler düzenlemek, dilekçeler göndermek, gösteriler, resmi kortejler, kamp kurma, işgal (occupy) eylemleri, oturma eylemi, grev, insan zinciri, hareketsiz durma eylemi gibi çeşitli eylemler bu gruba dâhildir.

\section{Yeni Toplumsal Hareketler Kuramına Yönelik Eleştiriler}

Modern toplumsal yapıdaki farklı kimlik ve eğilimlerin görünür hale gelmesi, ekonomik ve politik sorunların yerel ve ulusal sınırları aşarak küresel ölçeğe de yansımaya başlamasıyla 
yeni hareketlerin görece daha gevşek ve yerel örgütlenme yöntemi daha fazla sayıdaki toplumsal harekette kendini göstermeye başlamıştır. Yeni toplumsal hareketlerin açıklaması tek bir kuramda bulunmadığı gibi, farklı kuramcıların hareketlerin nedenleri ve dinamiklerini açıklamadaki farklılıkları temel olarak toplumsal hareketlerde "yeni"nin ne olduğu sorusunu da beraberinde getirmektedir.

Hareketlerin yeniliğinin eski hareketlerden kopuş olarak değerlendirilmesine karşı çıkan görüş, kavramın eski ile olan farklılıklarının abartıldığını ve yeni ile eski arasındaki benzerliklerin ise belirsizleştirildiğini vurgulamaktadır. Yeni kavramına atfedilen stratejik değer tarihin ana ajanı olarak "eski" işçi sınıfı hareketini gören Marksist gelenekten bir kopuşu simgeliyor olsa da, odağ 1 diğer aktörlere kaydırmak bu grupların 1960'ların protesto döngülerinden önce hiçbir tarihsellik taşımadığı iddiasını taşımaktadır. Ancak kadınlar, öğrenciler, etnik kimlikler, ırklar veya cinsel azınlıklar gibi grupları ve barış, ekoloji veya adalet temalarını içeren hareketlerin tümünün 20 . yüzyıla yayılan önemli tarihsel öncüleri bulunmaktadır (Buechler, 1995: 449). Klasik Marksist geleneğin 1960'larla birlikte hızla yayılan kimlik yönelimli hareketleri açıklamada işlevsiz kaldığını belirten YTH kuramcılarına yönelik bir başka eleştiri ise, kapitalist devleti dönüştürerek yine kapitalist toplumsal ilişkileri kabul ettiklerini ve kapitalist devletle yüzleşmekten uzak durdukları yönündedir (Mooers ve Sears, 1992, aktaran Buechler, 1995:450).

Benzer şekilde Çetinkaya (2008) da 18. yüzyıldan itibaren görülmeye başlanan hareketlerle yeni olarak tanımlanan hareketler arasında ciddi benzerlikler olduğunu vurgulamaktadır. $\mathrm{Bu}$ konuya örnek olarak, hareketlerin kimlik üzerinde durması, farklı araçlar kullanması ve gündelik hayatı siyasallaştırması gibi özellikleri geçen yüzyıldan beri gerçekleşen milliyetçilik hareketlerinde de görüldüğünü belirtmektedir (2008: 36-37).

Yeni toplumsal hareketlerin temel aktörlerinden biri olarak ele alınan orta sınıfa ilişkin "orta sınıfın eski tip toplumsal hareketlerde yer alıp almadığı" sorusu önem kazanmaktadır. "Yeni" olanın özgünlüğü tartışılırken, orta sınıf eylemlerinin 1800'lerin başından itibaren Avrupa ve Amerika’da görüldügünü ve eylemlerin yasaklama, yürürlükten kaldırmaya yöneldiği ve ilerici hareketler içerdiğini söylemek mümkündür. Dolayısıyla, orta sınıfın ilk kez yeni toplumsal hareketlerde toplumsal aktör olarak ortaya çıktığı argümanı tartışmaya açıktır (Pichardo, 1997: 418). Aynı zamanda, özellikle kopuş teorisi bağlamında açıklanan yeni toplumsal hareketlerin taleplerinin tamamen kimlik ve post-materyal değerler üzerinden şekillendiği yönündeki analizine karşs da süreklilik teorileri bağlamında bir eleştiri gelmektedir. Hareketlerin heterojen bir kimlik taşıdığı ve eski tip kolektif davranışların var olmaya devam ettiğini hatta bazı hareketlerde istatistiksel olarak ağır bastıkları söylenebilir (Cohen, 1999).

YTH teorileri tarafından kavramsallaştırılan siyaset alanında yeni hareketlerin nasıl bir gelecek kurgusu tasarladığının belirsiz bırakılması ve alternatif bir model sunulmaması da bir diğer önemli eleştiridir. Küreselleşme döneminde, siyasal partilere yöneltilen alternatif bir gelecek sunma anlamında "siyasal olmama" eleştirisinin yeni toplumsal hareketler için de geçerli olduğunu vurgulayan Çitçi (2008), yeni toplumsal hareketlerin bu özellikleri nedeniyle siyasal partilere bir seçenek olarak görülmesini olanaksız kıldığına değinmektedir. Crossley’e (2002:149) göre ise "Yeni Toplumsal Hareketler" kavramı hızla son kullanma tarihine yaklaşmaktadır. Yeni 
toplumsal hareketler kavramının atıf yaptığı 1960 'larda ortaya çıkmış birtakım hareketlerin çoğunun artık yeni değildir. Benzer şekilde Tarrow’a göre yeni toplumsal hareketler kapsamında farklı hareketler ortaya çıkmaktadır (2011).

Yeni toplumsal hareketler üzerine yapılan değerlendirmelerde, bu hareketlerin geçici nitelikleri, sınıfsal ve ideolojik temellerinin olmaması, yaşam kalitesiyle ilgili özgül talepler üzerinde odaklanmaları yönleriyle temsili demokrasinin enstrümanı olarak işlev gören siyasal partilerle bağların reddine ilişkin bir çerçeve sunulmaktadır. Ayrıca, alternatif bir gelecek sunma arayışının olmaması da kapitalist toplumun çelişkilerini hem eleştirmekte hem de bu toplum yapısı içerisinde var olmaya devam etmektedir. Bu bağlamda yeni toplumsal hareketlerin kurguladıkları siyasal alanın siyaset aktörleri ve gelecek bağ 1 ile kurduğu ilişkinin bir bütün olarak sağlam olmadığı söylenebilir.

\section{Sonuç}

Toplumsal alanda yaşanan değişim ve dönüşümün toplumsal olanla sınırlı kalmadığı politik ve ekonomik dönüşümü de etkilediği muhakkaktır. Toplumsal olanın nasıl tanımlandığı, siyasi alanla nasıl bir ilişki kurduğu ve gelecek tasavvurunu nasıl yaptı̆̆ı veya alternatif bir gelecek sunup sunmadığı soruları ise yeni toplumsal hareketlerin temel analiz öğelerini oluşturmaktadır. YTH teorilerinin kuramcılarına göre, yeni toplumsal hareketlerin farklıllğı, yeni dönem çatışma ve çelişkilerine bağlı olarak maddi talepler yerine değer ve kimlik yönelimli taleplerin siyasallaştırılması; siyasallaşma çabası içindeki bu taleplerin yalnızca sınıfsal aidiyetler ile tanımlanan gruplar yerine genel bir dünya görüşüne sahip ve modernizmin eleştirisinin parçalarını oluşturan bir ittifak tarafından dile getirmesidir. Taleplerin siyasal alanda karşılık bulabilmesi için kullanılan yöntem ise, kurumsal politikanın dışındaki kanalların kullanılmasıdır. Böylece hareketler, ağlar, sosyal medya, forumlar, platformlar gibi zayıf bağlarla birbirine bağlanmakta ve mücadelesini bu kanallarla sürdürmektedir.

Yeni toplumsal hareketlerin kuramsal açıklamalarına getirilen eleştiriler ise ağırlıklı olarak 'yeni' olanın içeriğinin muğlak kalması ve 'eskiden tamamen kopuş çıkarımının hareketlerin analizinde yetersiz kaldığıyla ilgilidir. Ayrıca, hareketlerin gelecek perspektifinin olmayışı, kopuk ve parçalı bir görünüm sergilemesi de hareketleri bir bütün olarak analiz etmeyi zorlaştırmaktadır.

Küreselleşmenin ağırlığını hissettirdiği günümüzde, küreselleşmenin toplumsal yaşam ve kültür üzerindeki etkilerine karşı direnç ve tepki gösteren yeni mücadeleler ortaya çıkmaktadır. 21. yüzyılda yükselen Küresel Adalet Hareketi gibi küresel hareketler, 'eski' ve 'yeni' olarak tanımlanan hareketlerin özelliklerine sahip birçok mobilizasyonun bileşimi hâlinde meydana gelmektedir. Kökleri 1960'lardan itibaren ortaya çıkan 'yeni' hareketlere dayanan bu geniş kitlelere ve coğrafyalara yayılan günümüzün bu küresel hareketlerinin daha iyi anlaşlabilmesi için, YTH teorilerinin analizlerini de dikkate alarak, 'yeni' ve 'eski hareketlerin farklılıklarını, benzerliklerini ve kesişim noktalarını tarihsel bir süreç içerisinde ele alınması gerekmektedir. Böylelikle, hem toplumsal öznenin hem de siyasal alanın son dönem tanımlamasında yeni bir gelecek perspektifi sunabilme imkânı geliştirilebilecektir. 


\section{Kaynakça}

Bebbington, A. (2007) "Social Movements and Politicization of Chronic Poverty", Development and Change, 38(5): 793-818.

Buechler, S. M. (1995) “New Social Movement Theories”, The Sociological Quarterly, 36(3): 441-464.

Castells, M. (2008 [1997]) Kimliğin Gücü Enformasyon Çağı-Ekonomik Toplum ve Kültür, 2. Cilt, çev. Ebru Kılıç, İstanbul: Bilgi Üniversitesi Yayınları.

Cohen, J. (1985) "Strategy or Identity: New Theoretical Paradigms and Contemporary Social Movements", Social Research, 52(4): 184-187.

Crossley, N. (2002) Making Sense of Social Movements, Philadelphia: Open University Press.

Çetinkaya, Y. D. (der.) (2008) Toplumsal Hareketler: Tarih, Teori ve Deneyim, İstanbul: İletişim Yayınları.

Çitçi, O. (2008) "Yeni Siyaset: Neoliberalizm ve Postmodernizmin Siyasal Projesi”, YDÜ Sosyal Bilimler Dergisi, 1(2): 2-32.

Della Porta, D. ve M. Diani (1999) Social Movements: An Introduction, Oxford: Blackwell.

Dirlik, A. (2008) "Pasifik Perspektifinde Toplumsal Hareketler, Çağdaş Radikal Siyasetin Soyağacı Üzerine Düşünceler, Tarih ve Kuram Arasında Toplumsal Hareketler”, Y. D. Çetinkaya (der.), Toplumsal Hareketler: Tarih, Teori ve Deneyim içinde, İletişim Yayınları, İstanbul.

Eder, K. (1985) “The "New Social Movements": Moral Crusades, Political Pressure Groups, or Social Movements?", Social Research, 52(4): 869-890.

Habermas, J. (1981) "New Social Movements", Telos, 49: 33-37.

Kartal, B. ve B. Kümbetoğlu (der.) (2012) Yeni Toplumsal Hareketler, Eskişehir: Açık Öğretim Fakültesi Yayınları.

Laclau, E. Ve C. Mouffe (1985) Hegemonya ve Sosyalist Strateji: Radikal Demokratik Bir Politikaya Doğru, çev: Ahmet Kardam, İstanbul: Birikim, 1992.

Melucci, A. (1985) "Symbolic Challenge of Contemporary Movements", Social Research, 52(4): 789-816.

Mouffe, C. (1984) “Towards a Theoretical Interpretation Of New Social Movements", S. Hanninen, and Paldan (der.), Rethinking Marx içinde, Berlin: Argument Sonderband, 139-143.

Offe, C. (1985) "New Social Movements: Challenging the Boundaries of Institutional Politics", Social Research, 52(4): 817-868.

Pichardo, N.A. (1997) “New Social Movements: A Critical Review.” Annual Review of Sociology, 23: 411-430.

Scott A. (1990) Ideology And The New Social Movements, London: Unwin Hyman Ltd.

Tarrow, S. (2011) Power in Movement: Social Movements and Contentious Politics, Updated and Revised 3rd Edition, Cambridge University Press.

Tilly, C. (2008 [2004]) Toplumsal Hareketler 1768-2004, çev. O. Düz, İstanbul: Babil Yayınları.

Touraine, A. (1988) Return of the Actor: Social Theory in Postindustrial Society, Minneapolis: University of Minnesota Press.

Touranie, A. (1999) Toplumdan Toplumsal Harekete, Yeni Sosyal Hareketler/Teorik Açllımlar, haz. Kenan Çayır, İstanbul: Kaknüs Yayınları.

Yıldırım, Y. (2012) Yeni Toplumsal Hareketlerin Siyasal Olanı Belirlemedeki Rolü: Avrupa Sosyal Forumu ve Hareketlerin Avrupa'sını Kurmak, Yayımlanmamış Doktora Tezi, Ankara Üniversitesi Sosyal Bilimler Enstitüsü, Ankara. 